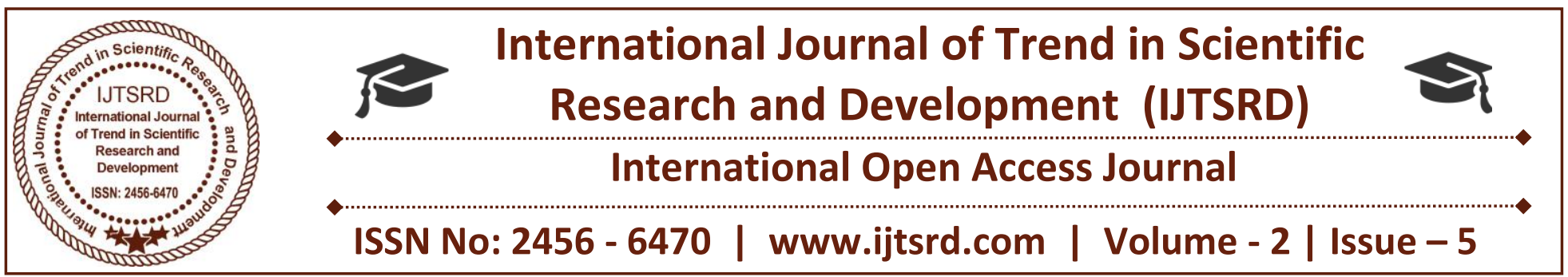

\title{
Efficacy of Leaves of Lantana Camara as Mosquito Repellent
}

\author{
Gamit Shraddha, Shreya Desai, Jemisha Mistry, \\ Swetal Patel, Rajashekhar Ingalhalli \\ C. G. Bhakta Institute of Biotechnology, Maliba Campus, \\ Bardoli Mahuva Road, Tarsadi, Surat, Gujarat, India
}

\begin{abstract}
There are so many diseases which are spread by mosquitoes and for their control aspects there are numbers of products which are available. To overcome the harmful effects of commercially available mosquito repellent formulations, herbal formulations can help in developing eco friendly and cheaper alternatives. With this view in mind Lantana camera leaf powder was utilized to make incense sticks and used to evaluate mosquito repellence by smoke toxicity test and compared with commercial product. The test revealed that the control could show that the control (commercial product) 100\% mortality in just 2 minute and took 30 minutes for complete burning. It created some side effects like headea, watery eye and coughing in some member. The experimental product took 40 minutes for complete burning with $100 \%$ mortality with any side effect. The cost of experimental product just $25 \%$ of commercial product. The presence of different phytochemicals in different solvent extract corroborates the insecticidal activity. Antibacterial activity was also found against three test organism Escherichia coli, Pseudomonas sp. and B.megaterium. This result may be use for conformation and development drugs.
\end{abstract}

\section{INTRODUCTION}

Mosquitoes are the major public health problem throughout the world. Among the 3492 species of mosquitoes recorded worldwide, more than a hundred species are capable of transmitting various diseases in human and other vertebrates [1]. Mosquitoes transmit malaria, dengue fever, yellow fever, filariasis, and chikungunya to humans [2]. Mosquitoes are tiny blood-sucking insects that depend on standing water to reproduce. Female mosquitoes must feed on blood to lay eggs. They feed by piercing their mouthparts into the skin of an animal and sucks blood rapidly. More often, they carry viruses that can be transmitted to a person while they are feeding [3].

Environmental conditions like temperature and moisture are where the length of mosquito life cycle between species depends. Nonetheless, the life cycle of all mosquitoes consists of the egg, larval, pupal and adult stages. Male mosquitoes feed on the nectar of the plants only, while females extract the blood of the hosts in order to develop and nourish eggs. Nearly all mosquitoes lay their eggs directly into water and others lay their eggs just near but not in the water. Within 24 to 48 hours, the eggs will hatch into larvae. The larvae will soon grow approximately $5 \mathrm{~mm}$ in length. They breathe through siphon or air tubes. The larger ones can be seen floating just above the surface of waters that are infested. Within a span of seven to 10 days, the larvae will enter the stage of a pupa. Pupae are also visible upon the surface of the breeding site. When a mosquito is fully developed, it will emerge from its pupal case and will become a mosquito. The new adult, at this time, will stand upon the water to dry its wings and prepare for its flight. The female mosquitoes will then seek an animal to suck on and feed. They are capable of flying for miles and lay over 100 eggs at a time. Larvae and pupae ordinarily cannot survive without water. If a water source evaporates while they are still in these stages, they will die [4].

Several approaches were extensively used to control the threat posed by these mosquitoes. Over the years, synthetic insecticides were introduced But, although these are effective, the insects tend to develop resistance to such products [5]. Aside from being 
costly, the use of these repellents also generates problems such as environmental pollution and has toxic side effect on humans [6]. This creates a need for other alternative methods which are efficient, economical and environmentally safe. Botanical derivatives can materialize as a possible larvicides for the Aedes aegypti or the common household mosquitoes [7].

Plants, being a natural source of various compounds are known to contain larvicidal agents, which may act in combination or independently [8]. Phytochemicals act as general toxicants both against the adult as well as larval stages of mosquitoes, while others interfere with the growth and development, reproduction, produce olfactory stimuli action as a repellent. Natural products are best option because they are less harmful to environment and non-target organisms. Several extracts and compounds from different plants families have been evaluated for new and promising larvicides [9].

Lantana camara Linn (Verbenaceae) is also known as wide sage or lantana weed. It is a hefty extensive evergreen shrub which can grow up to $3 \mathrm{~m}$ in height and has a strong scent. It is a perpetual shrub found growing up to $2000 \mathrm{~m}$ altitude in tropical, subtropical and climate parts of the world. Different parts of this plant have been used conventionally for numerous illnesses through the world. The leaves of this plant were used as an antibacterial and antihypertensive agent, roots for the treatment of malaria, rheumatism, and skin rashes [10]. Extract from the leaves of Lantana camara possesse larvicidal activity while extract from flowers of the plant showed repellent activity against adult mosquitoes [11].

\section{Scientific classification}

$>$ Kingdom : Plantae

$>$ Order : Lamiales

$>$ Family : Verbenaceae

$>$ Genus : Lantana

$>$ Species : camara

\section{OBJECTIVES}

$>$ To produce an effective and natural mosquito coil/incense stick using L. camera leaves.

$>$ To find out if the product is an alternative to already available mosquito coil/stick in the market.
$>$ To demonstrate the significant difference between experimental product and the commercial product in terms of effectiveness.

\section{Materials and methods: \\ 2.1 Collection of plant material \\ Collection of leaves}

Lantana camara leaves were collected during month of October (2017), from rural area near Uka Tarsadia University, Bardoli. The Leaves were washed in running tap water, air dried in shade and then homogenized to make fine powder. This powder was packed in air tight polythene bags until further use.

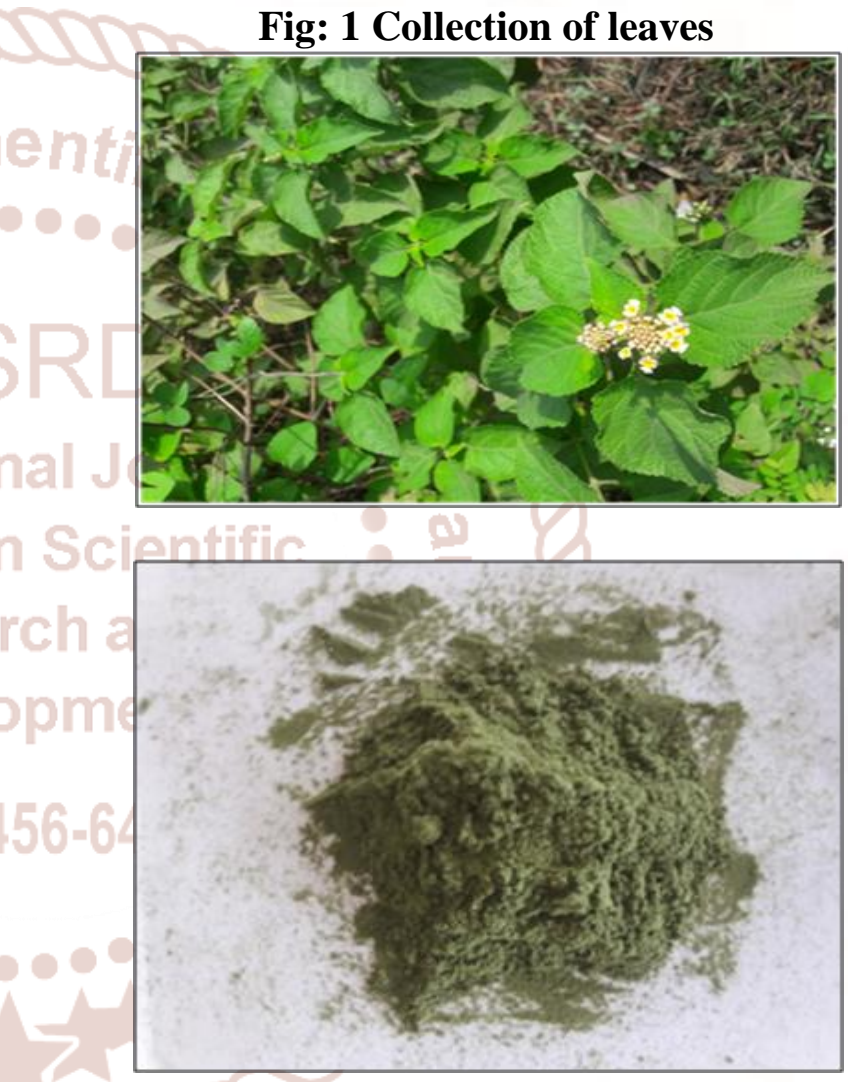

2.2: Phytochemical Analysis:

2.2.1 Qualitative Analysis:

\subsubsection{1: Alkaloids}

Crude extract was mixed with $2 \mathrm{ml}$ of $1 \% \mathrm{HCl}$ and heated gently. A Mayer's And Wagner's reagent was then added to the mixture. Turbidity of the resulting precipitate was taken as evidence for the presence of alkaloids [12].

\subsubsection{2: Glycosides}

Crude extract was mixed with each of $2 \mathrm{ml}$ of chloroform and $2 \mathrm{ml}$ of acetic acid. The mixture was cooled in ice. Carefully concentrated $\mathrm{H} 2 \mathrm{SO} 4$ was 
added. A colour change from violet to blue to green indicated the presence of steroidal nucleus, glycine portion of glycoside [12].

\subsubsection{3: Flavonoid}

When dilute sodium hydroxide was added to $0.2 \mathrm{ml}$ of extract it created intense yellow colour, On addition of $\mathrm{HCl}$ it turned colourless which suggests the presence of flavonoids [13].

\subsubsection{4: Carbohaydrate}

$1 \mathrm{ml}$ of distilled water and 5-8 droup of fehling's solution was added to $0.5 \mathrm{ml}$ of plant extract and allowed to $60^{\circ} \mathrm{C}$ for $15 \mathrm{~min}$. Formation brick red precipitate indicated the presence of carbohaydrate.

\subsubsection{5: Tannins}

Crude extract was mixed with $2 \mathrm{ml}$ of $2 \%$ solution of $\mathrm{FeCl} 3$. A blue-green or black coloration indicated the presence of tannins [13].

\subsection{Preparation of incense sticks}

The incense sticks were prepared using the powder, binding agent and burning agent at Mahavir Agarbatti Works at Vyara.

\subsection{Mosquito repellence test}

\subsubsection{Mosquito Larvae Collection}

The mosquito larvae and pupae were collected from Uka Tarsadia University campus. The mosquito larvae were maintained at room temperature. The larvae were fed with Bagasse.

\subsubsection{Microscopic examination larva}

Larva sample was taken with the help of a dropper and placed on a slide. It was observed under $10 \mathrm{x}$ in compound microscope.

\subsubsection{Smoke toxicity test}

Smoke toxicity test was conducted in a chamber measuring $34.5 \times 24 \times 29.5 \mathrm{~cm}$. Then adult mosquitoes were released in to the chamber and they were exposed to the smoke of burning incense stick for 45 min. The mortality data were recorded after every $15 \mathrm{~min}$. The smoke toxicity was compared with the commercially available citronella incense stick as tested above [14].

\subsubsection{Evaluation of burning on users}

For investigating mosquito repellent activity the prepared incense sticks were checked for its burning time with respect to flammability. Further its causal effect such as irritation, coughing, tears were observed and recorded. Mosquito repellence test was done by simply selecting the mosquito prone areas in the evening and night period. The public remarks were noted down after the test [14].

\subsection{Larvicidal activity}

\subsubsection{Preparation of plant extracts:}

The prepared powder was put in each of water, petroleum ether, chloroform, and ethyl acetate solvents (plant material to solvent ratio was 1:10, w/v) and extracted for $24 \mathrm{~h}$ at room temperature with shaking at $150 \mathrm{rpm}$. The extracts were filtered and dried at $40^{\circ} \mathrm{C}$. The dried extracts were resuspended in $1 \mathrm{ml}$ of acetone.

\subsubsection{Biological assay:}

Prepare different concentration of extract in distilled water. Every experimental exposure was done in petri-plate. Twenty-five (25) larvae were collected with a pasture pipette, placed on a filter paper for removal of excess of water and placed in $25 \mathrm{ml}$ tap water containing various concentration of crude extracts. Control test was done in $25 \mathrm{ml}$ distilled water with 25 larvae. The petri-plates were covered with muslin cloth to avoid entry of any foreign material. Sufficient control was also kept for each extracts. The observed mortality was recorded at $24 \mathrm{~h}$ of period exposure to test solution. From this crude mortality, if any, was recorded and percentage crude mortality was obtained [15].

Percentage of mortality $=1-$

$\frac{\text { population in treated plot after treatment }}{\text { population in control plot after treatment }} \times 100$

\section{Results}

\subsection{Phytochemical Analysis:}

The phytochemicals and elemental analysis of leaf of Lantana camara showed the presence of useful classes of chemical compounds such as Alkaloids, Glycosides, Carbohydrate, Flavonoid and Tannins compounds. Table 1 shows the phytochemical results of Lantana camara.

Table: 1 Phytochemical Analysis of leaf extract

\begin{tabular}{|c|c|c|c|}
\hline No & Test & Methanol & Aqueous \\
\hline 1 & Alkaloids & -ve & + ve \\
\hline 2 & Glycosides & + ve & $+v e$ \\
\hline 3 & Carbohydrate & $+v e$ & -+ve \\
\hline 4 & Flavonoids & $+v e$ & $+v e$ \\
\hline 5 & Tannins & $+v e$ & $+v e$ \\
\hline
\end{tabular}


International Journal of Trend in Scientific Research and Development (IJTSRD) ISSN: 2456-6470

Fig : 2 Result of Qualitative Analysis
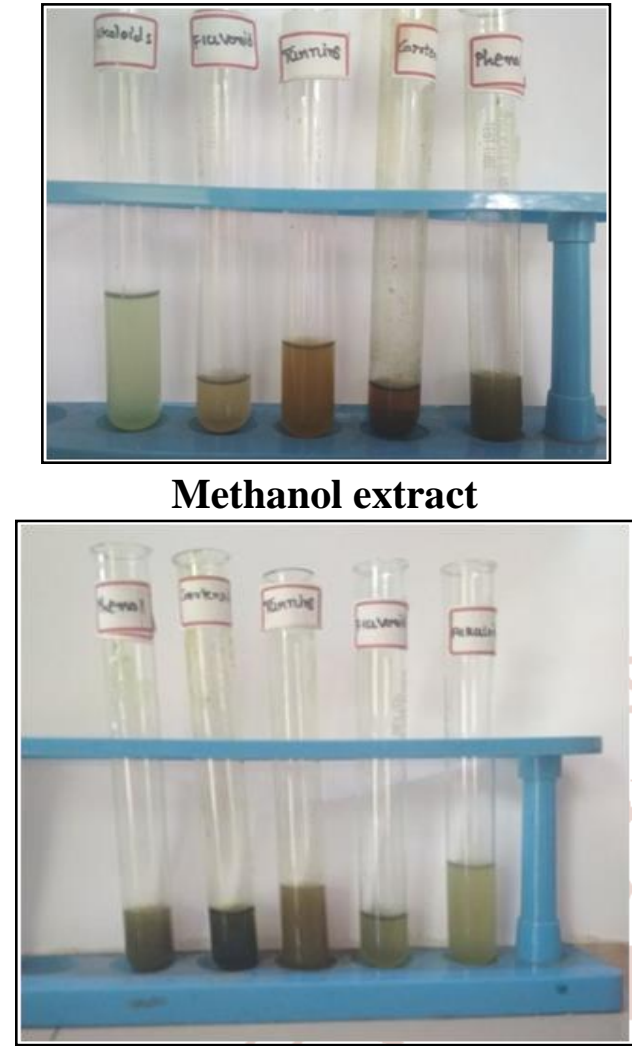

Aqueous extract
Table: 2 Cost of stick

\begin{tabular}{|c|c|c|}
\hline & $\begin{array}{c}\text { Incense Stick } \\
(80 \% \text { charcoal })\end{array}$ & $\begin{array}{c}\text { Incense Stick } \\
(75 \% \text { charcoal })\end{array}$ \\
\hline $\begin{array}{c}\text { Weight of } \\
\text { crude power }\end{array}$ & $300 \mathrm{gm}$ & $50 \mathrm{gm}$ \\
\hline $\begin{array}{c}\text { Total } \\
\text { number of } \\
\text { incense } \\
\text { stick }\end{array}$ & 3200 & 270 \\
\hline $\begin{array}{c}\text { Total cost } \\
\text { of incense } \\
\text { stick }\end{array}$ & Rs 750 & Rs 27 \\
\hline stick cost & 20 paisa & 10 paisa \\
\hline
\end{tabular}

Table: 3 Ingredient in sticks

\begin{tabular}{|c|c|c|}
\hline Ingredient & $\begin{array}{c}\text { Composition } \\
(\%)\end{array}$ & $\begin{array}{c}\text { Composition } \\
(\%)\end{array}$ \\
\hline Leaf material & $20 \%$ & $25 \%$ \\
\hline $\begin{array}{c}\text { Charcoal and } \\
\text { binding agent }\end{array}$ & $80 \%$ & $75 \%$ \\
\hline Total amount & $100 \%$ & $100 \%$ \\
\hline
\end{tabular}

\subsection{Mosquito repellence test}

\subsubsection{Mosquito Larvae Collection}

The mosquito larvae and pupae were collected from

3.3 Preparation of incense sticks

Incense sticks with leaf powder were prepared and used to test the efficacy against mosquito by smoke toxicity test.

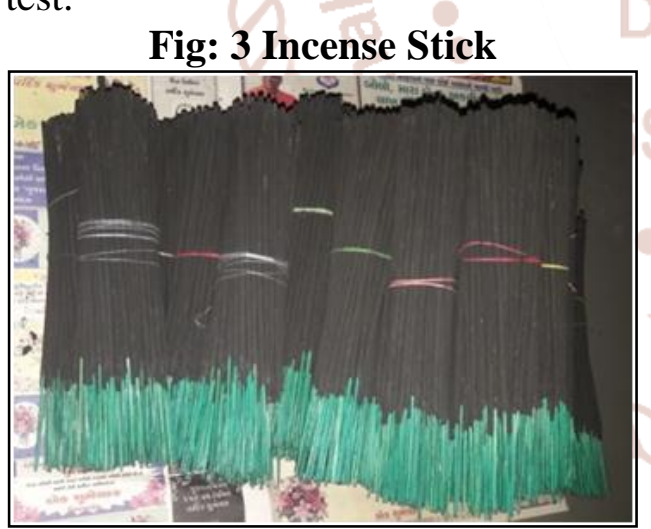

Incense Stick $(80 \%$ charcoal $)$

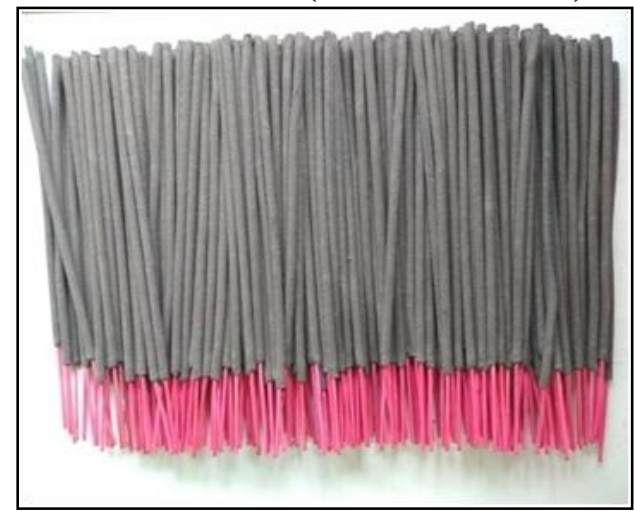

Incense Stick (75\% charcoal )
Fig : 4 Mosquito Larvae Collection

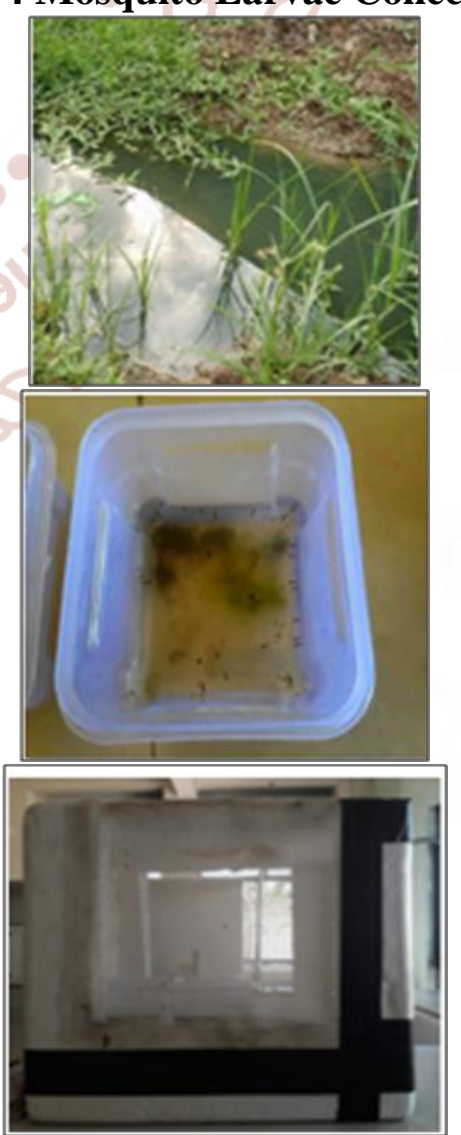


Fig: 5 Microscopic examination larva By the help of dropper took larva sample and than place it on slide and observe under $10 \mathrm{x}$ in compound microscope.

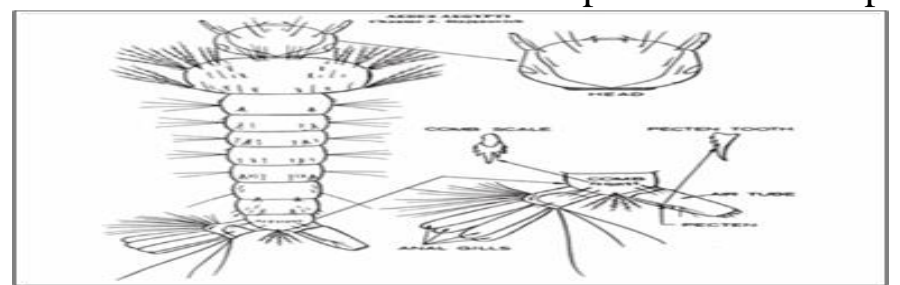

(Fmel.ifas.ufl.edu)
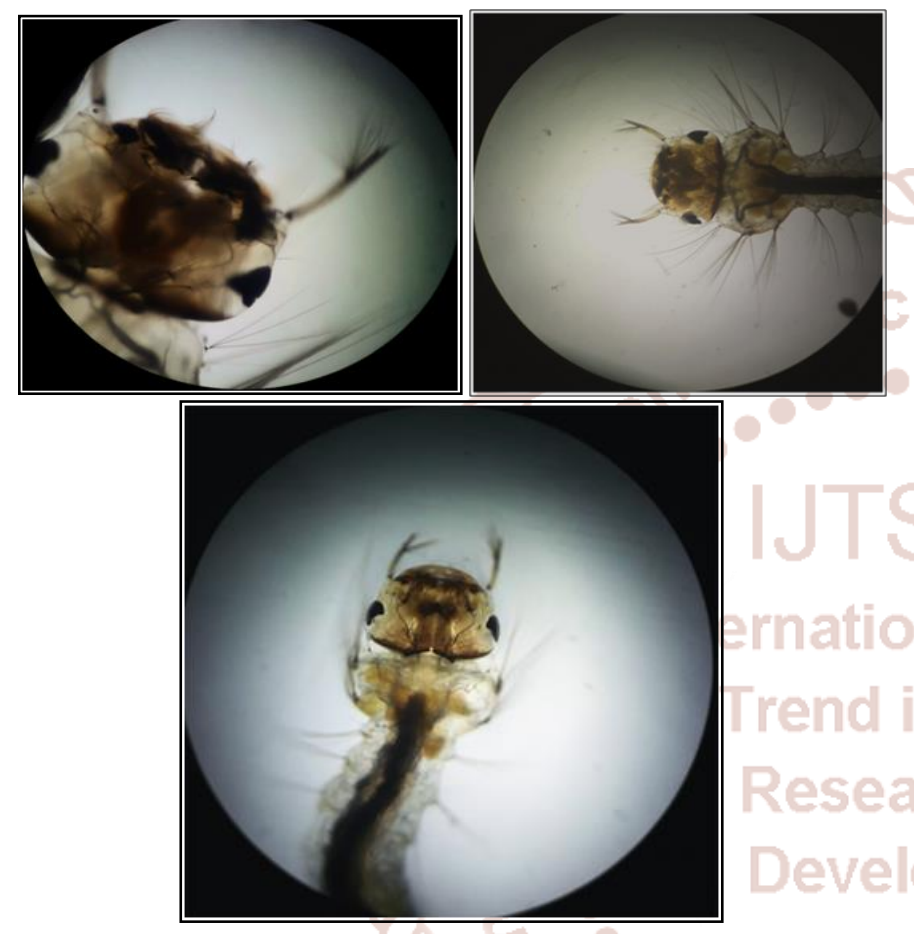

Table: 4 Result of smoke toxicity test

Incense sticks ( $80 \%$ charcoal and $20 \%$ leaf sample)

\begin{tabular}{|c|c|c|c|c|c|c|}
\hline Sr. no & $\begin{array}{c}\text { No. of } \\
\text { mosquitoes }\end{array}$ & $\begin{array}{c}\text { No. of dead } \\
\text { mosquitoes }\end{array}$ & $\begin{array}{c}\text { No. of live } \\
\text { mosquitoes }\end{array}$ & $\begin{array}{c}\text { Time } \\
(\mathbf{m i n})\end{array}$ & $\begin{array}{c}\text { Temperature } \\
\left({ }^{\circ} \mathrm{C}\right)\end{array}$ & $\begin{array}{c}\text { Burning time } \\
(\mathbf{m i n})\end{array}$ \\
\hline Control & 25 & 25 & 0 & 2 & 31 & 31 \\
\hline Test 1 & 25 & 30 & 5 & 40 & 31 & 40 \\
\hline Test 2 & 30 & 28 & 2 & 40 & 36 & 42 \\
\hline Test 3 & 35 & 33 & 2 & 44 & 38 & 39 \\
\hline
\end{tabular}

Table: 5 Result of smoke toxicity test Incense sticks (75\% charcoal and $25 \%$ leaf sample)

\begin{tabular}{|c|c|c|c|c|c|c|}
\hline Sr. no & $\begin{array}{c}\text { No. of } \\
\text { mosquitoes }\end{array}$ & $\begin{array}{c}\text { No. of dead } \\
\text { mosquitoes }\end{array}$ & $\begin{array}{c}\text { No. of live } \\
\text { mosquitoes }\end{array}$ & $\begin{array}{c}\text { Time } \\
(\mathbf{m i n})\end{array}$ & $\begin{array}{c}\text { Temperature } \\
\left({ }^{\circ} \mathbf{C}\right)\end{array}$ & $\begin{array}{c}\text { Burning time } \\
(\mathbf{m i n})\end{array}$ \\
\hline Control & 15 & 10 & 5 & 2 & 31 & 31 \\
\hline Test 1 & 15 & 10 & 5 & 30 & 37 & 46 \\
\hline Test 2 & 10 & 8 & 2 & 28 & 36 & 45 \\
\hline Test 3 & 10 & 8 & 2 & 20 & 37 & 42 \\
\hline
\end{tabular}


Fig: 6 Smoke toxicity
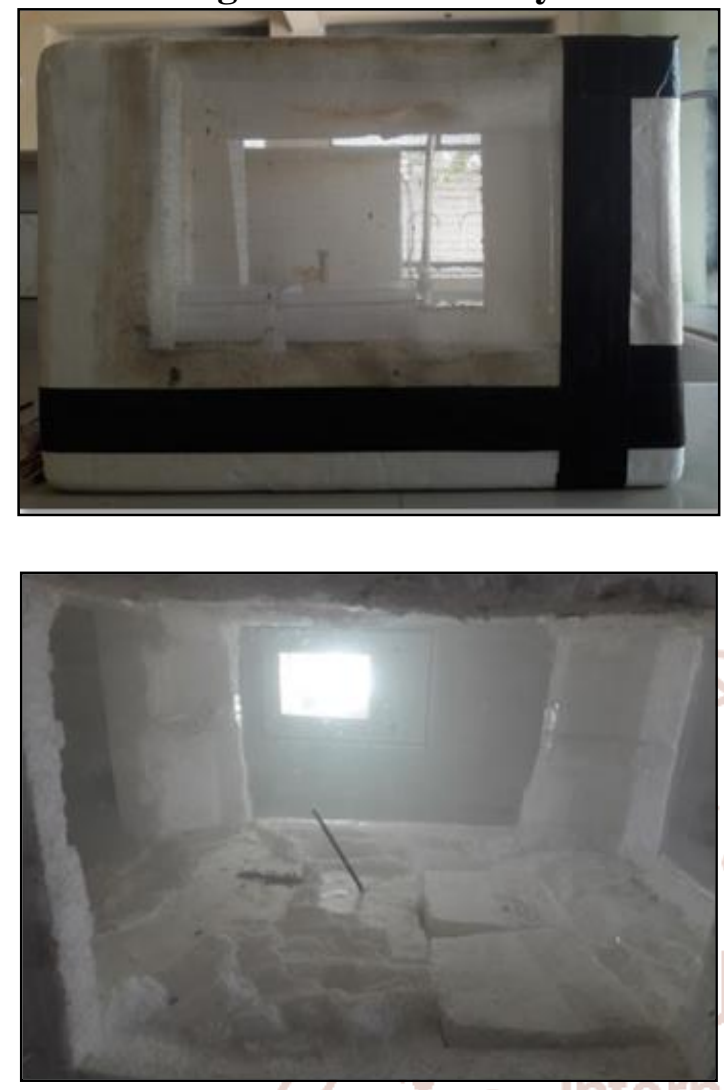

\section{5 larvicidal activity}

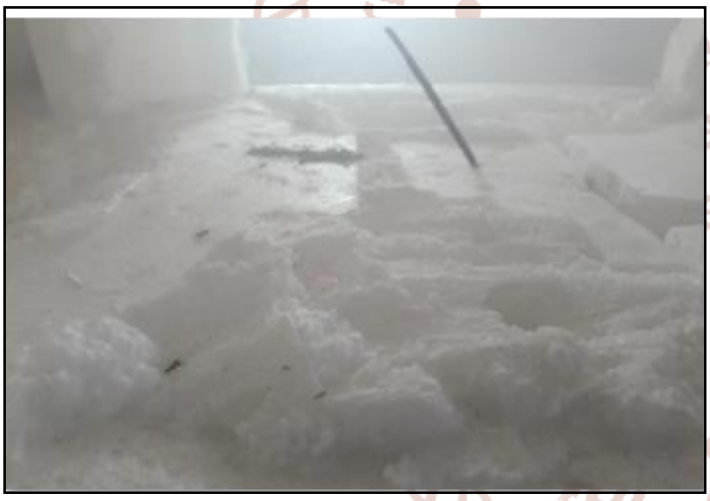

\subsubsection{Evaluation of burning on users}

Test was done by simply selecting the mosquito prone areas in the evening and night period. The public remarks were noted down after allowing them. For investigating mosquito repellent activity the prepared incense sticks were checked for causal effect such as irritation, coughing, and tears were observed and recorded. Ash produced by the stick was weighed and recorded.

\section{Table: 6 Investigating mosquito repellent activity} in open

\begin{tabular}{|c|c|c|c|}
\hline $\begin{array}{c}\text { Sr. } \\
\text { No. }\end{array}$ & Areas & $\begin{array}{c}\text { Observation given } \\
\text { by people }\end{array}$ & Remarks \\
\hline 1 & Hostel & $\begin{array}{c}\text { Mosquitoes escaped } \\
\text {, Less irritation, no } \\
\text { coughing, tears. }\end{array}$ & $\begin{array}{c}\text { Mosquito } \\
\text { repelled }\end{array}$ \\
\hline 2 & Canteen & $\begin{array}{c}\text { Mosquitoes escaped } \\
\text {,No irritation, no } \\
\text { coughing, no tears }\end{array}$ & $\begin{array}{c}\text { Mosquito } \\
\text { repelled }\end{array}$ \\
\hline 3 & $\begin{array}{c}\text { Rural } \\
\text { area near } \\
\text { pond }\end{array}$ & $\begin{array}{c}\text { Mosquitoes moved } \\
\text { outside the room, } \\
\text { No coughing, no tears }\end{array}$ & $\begin{array}{c}\text { Mosquito } \\
\text { repelled }\end{array}$ \\
\hline 4 & $\begin{array}{c}\text { Hospital } \\
\text { Mosquitoes moved } \\
\text { outside the room, } \\
\text { No coughing }\end{array}$ & $\begin{array}{c}\text { Mosquito } \\
\text { repelled }\end{array}$ \\
\hline 5 & Hotel & $\begin{array}{c}\text { Mosquitoes escaped } \\
\text { No irritation, no } \\
\text { coughing, no tears }\end{array}$ & Mosquito \\
repelled
\end{tabular}

Table: 7 Result of biological assay

\begin{tabular}{|c|c|c|c|c|c|}
\hline \multirow{2}{*}{ Extract } & Concentration & \multicolumn{2}{|c|}{ No. of larvae } & Time duration & \multirow{2}{*}{ Percentage of mortality } \\
\cline { 3 - 4 } & $(\mu \mathrm{g} / \mathrm{ml})$ & Exposed & Dead & & \\
\hline Distilled water & $50 \mu \mathrm{g} / \mathrm{ml}$ & 20 & 10 & 24 hours & $40 \%$ \\
\hline & $100 \mu \mathrm{g} / \mathrm{ml}$ & 20 & 12 & 24 hours & $48 \%$ \\
\hline Petroleum ether & $50 \mu \mathrm{g} / \mathrm{ml}$ & 20 & 0 & 24 hours & $0 \%$ \\
\hline & $100 \mu \mathrm{g} / \mathrm{ml}$ & 20 & 8 & 24 hours & $32 \%$ \\
\hline Chloroform & $50 \mu \mathrm{g} / \mathrm{ml}$ & 20 & 14 & 24 hours & $56 \%$ \\
\hline & $100 \mu \mathrm{g} / \mathrm{ml}$ & 20 & 18 & 24 hours & $72 \%$ \\
\hline Ethyl acetate & $50 \mu \mathrm{g} / \mathrm{ml}$ & 20 & 2 & 24 hours & $8 \%$ \\
\hline & $100 \mu \mathrm{g} / \mathrm{ml}$ & 20 & 1 & 24 hours & $4 \%$ \\
\hline
\end{tabular}


Fig : 8 Result of larvecidial activity
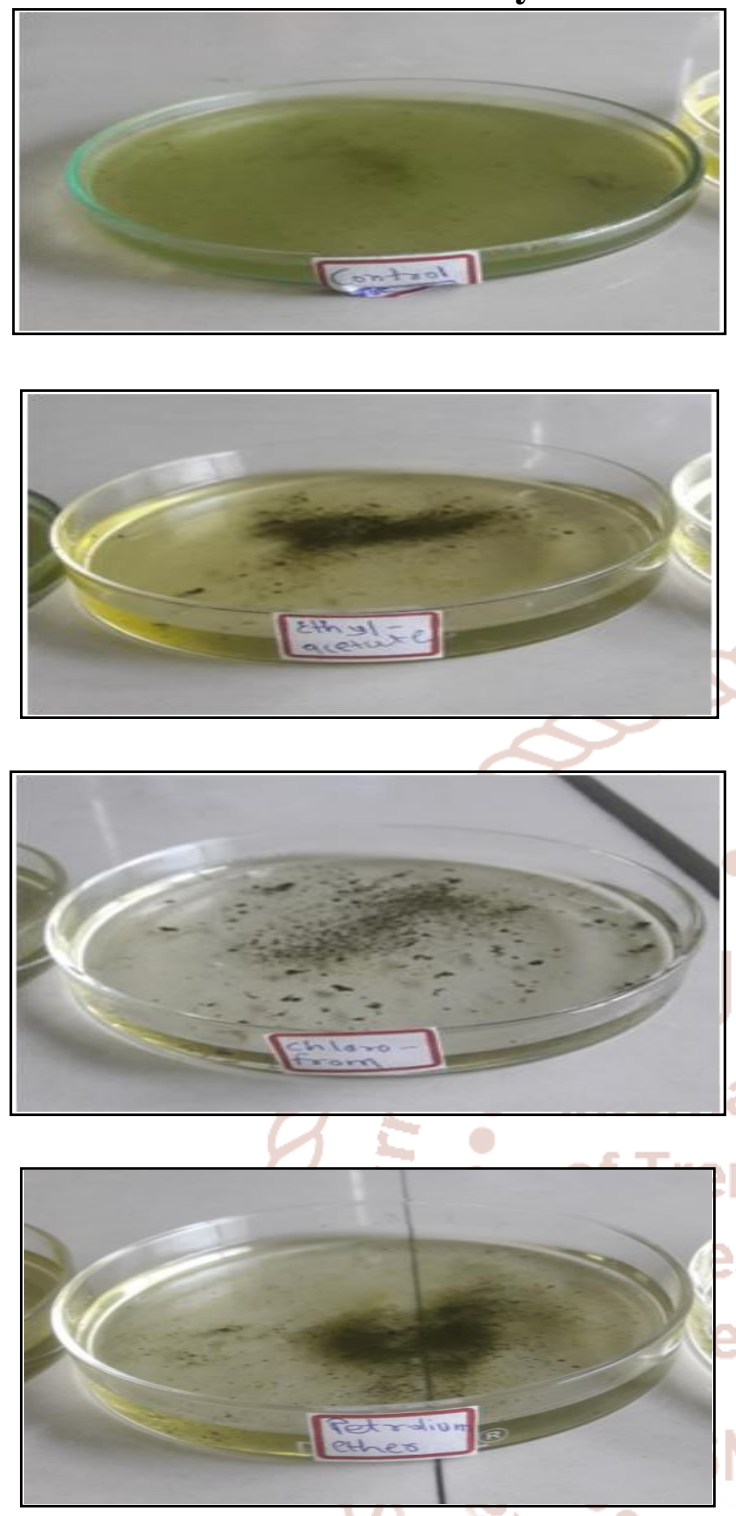

\section{Discussion}

Mosquitoes have been posing a deadly threat to man for a long time. Through some repellents in the market help in the control of mosquitoes to some element at the same time they induce certain side effects due to the presence of synthetic chemicals. Plant have been helpful in provide remedies in such case. Such plant products are safe environment friendly, cheaper and without any side effect.

Lantana camera is believed to be having insecticidal properties and this plant grows evergreen in tropical climate. This plant was selected to test the mosquito repellent activity. Leaf powder was select to make incense sticks which were burnt under different condition to observe the repellent of mosquitoes using smoke toxicity as a parameter.

Incense sticks were prepared at a factory in vyara with
$20 \% \& 25 \%$ leaf powder plus $80 \%$ and $75 \%$ charcoal and binding agent. Commercially available incense sticks (sleep well brand) were used.

The cost of product was calculated for both. The burning time of the experimental sticks was about forty five minutes $\&$ that of commercial product was about 30 minutes. $100 \%$ mortality was observed in just 2 minutes when commercial product was burn in experimental chamber. But its smell \& smoke created side effects like uneasiness, itching in eyes and coughing in some members. This may be due to the presence of some synthetic chemical. The experimental product took about 40 minutes for complete burning and $100 \%$ mortality. The smoke did not cause any side effect like coughing, uneasiness and itching in eyes as in commercial products. The cost of production is found to be just $25 \%$ of the commercial product.

Phytochemical evaluation of leaf extract in distilled water and methanol. it revealed that alkaloids, glycoside, carbohydrate, flavonoids and tannins were present in distilled water extract. In methanol extract alkaloids were found to be absent while glycoside, carbohydrate, flavonoids and tannins were presnt.

Antimicrobial against three bacterial species ( Escherichia coli, pseudomonas sp. and B. megaterium) using leaf extract in aceton, ethanol and distilled water in $20 \mu \mathrm{l} \& 40 \mu \mathrm{l}$. the antimicrobial activity was found in all the extract with $40 \mu 1$ concentration. The activity was absent against B.megaterium only at $20 \mu 1$ concentration in ethanolic extract but present against all three organisms in all three extracts at both the concentrations.

\section{References}

1. Rueda, L. M. (2008) Global diversity of mosquitoes (Insecta: Diptera: Culicidae) in freshwater. Hydrobiologia, 595(1), 477-487.

2. Nour, A. H., Elhussein, S. A., Osman, N. A., \& Yusoff, M. M. (2009). A study of the essential oils of four Sudanese accessions of basil (Ocimum basilicum L.) against Anopheles mosquito larvae. American Journal of Applied Sciences, 6(7), 1359-1363.

3. Mosquito-Borne Diseases. (2013). Retrieved June 3, 2013 from http://www.cdph.ca.gov/HealthInfo/discond/Pages /MosquitoBorneDisease s.aspx 
4. Mosquito Life Cycle. (2013). Retrieved June 3, 2013 from http://www.orkin.com/other/mosquitoes/mosquito -life-cycle/

5. Jirakanjanakit, N., Rongnoparut, P., Saengtharatip, S., Chareonviriyaphap, T., Duchon, S., Bellec, C., \& Yoksan, S. (2007). Insecticide susceptible/resistance status in Aedes (Stegomyia) aegypti and Aedes (Stegomyia) albopictus (Diptera: Culicidae) in Thailand during 2003-2005. Journal of Economic Entomology, 100(2), 545-550.

6. Sarwar, M., Ahmad, N., \& Toufiq, M. (2009). Host plant resistance relationshiphs in chickpea (cicer arietinum 1.) against gram pod borer (helicoverpa armigera hubner. Pakistan Journal of Botany, 41(6), 3047-3052.

7. Zhu, J., Zeng, X., O'neal, M., Schultz, G., Tucker, B., Coats, J., ... \& Xue, R. D. (2008). Mosquito larvicidal activity of botanical-based mosquito repellents. Journal of the American Mosquito Control Association, 24(1), 161-168.

8. Nivedita, G., Anand, P., \& Kondiram, D. (2010). Larvicidal activity of invasive weeds Cassia uniflora and Synedrella nodiflora. International Journal of Pharma and Bio Sciences, 1(3).

9. Innocent, E., Joseph, C. C., Gikonyo, N. K., Moshi, M. J., Nkunya, M. H., \& Hassanali, A. (2008). Mosquito larvicidal constituents from Lantana viburnoides sp viburnoides var kisi (A. rich) Verdc (Verbenaceae). Journal of vector borne diseases, 45(3), 240-244.

10. Thamotharan, G., Sekar, G., Ganesh, T., Sen, S., Chakraborty, R., \& Kumar, S. N. (2010). Antiulcerogenic effects of Lantana camara Linn. leaves On in vivo test models in rats. Asian journal of pharmaceutical and clinical research, 3(3), 57-60.

11. Kumar M S., \& Maneemegalai, S. (2008). Evaluation of larvicidal effect of Lantana camara Linn against mosquito species Aedes aegypti and Culex quinquefasciatus. Advances in Biological Research, 2(3-4), 39-43.

12. Harborne J B, (1973). Phytochemical Methods, Chapman and Hall, Ltd., London, pp. 49-188. 8.

13. Evans, W. C. (2002). Trease GE and Evans WC, (1989). Pharmacognosy, 13th edition, Balliere Tindall, London, pp. 176-80. Trease and Evans. WB Saunders Harcourt Publishers Ltd, 292, 357-75.

14. Rawani, A., Ghosh, A., Laskar, S., \& Chandra, G. (2012). Aliphatic amide from seeds of Carica papaya as mosquito larvicide, pupicide, adulticide, repellent and smoke toxicant. Journal of Mosquito Research, 2(1).

15. Malik, B. R., Malik, M. K., \& Balakrishnan, N. (2014). Evaluation of larvicidal activity of the different extracts against important species of mosquito: Anopheles stephensi. Journal of Parasitology and Vector Biology, 6(1), 11-15. 